\title{
Eğitimin Genel Amaçları Açısından Din Kültürü ve
} Ahlâk Bilgisi Dersleri

\section{Osman ĔGRİ}

Yrd. Doç. Dr., Gazi Üniversitesi Çorum İlahiyat Fakuiltesi

e-mail: osmanegri@yahoo.com

Abstract: Religious Culture and Moral Education in terms of General Aims of Education. The education is the fundamental dynamic of indivudil, social, and cultural life. There are general aims of education. These aims can be enumerate as such: Instruction of learning. Thinking, problem solving and creative thinking. We discussed in this article how can be transferred these aims to religious education.

Key Words: Education, Religious Education, Moral Education.

\section{Giriş}

Ĕgitim, insan varlığının derinliklerine ve özüne kök salan tutumları, davranışları, hayat felsefesini, hayatın anlamını, görevini ve sorumluluklarını, süregelen insan kültürüyle yoğurarak, bireyde ve toplumda değişme ve oluşmalar meydana getirme sürecidir.'

' Saffet Bilhan, Eğitim Felsefesi, Ankara, 1991, A. Ü. Eğitim Bilimleri F. Y., s. 121; Ferhan Oğuzkan, Eğitim Terimleri Sözlüğü, Ankara, 1981, Türk Dil kurumu Y., s. 57; Mustafa Ergün, Eğitim Felsefesi, Ankara, 1996, Ocak Y., s. 11. 
İnsanda doğal olarak bir eğitim vardır: Doğruya varmak, çevresinde olup bitenleri bilmek gibi. Insan, var olanı görmekle kalmaz; bunun varlık nedeni, dayandığı ilkeler hakkında da düşünme ihtiyacı duyar. Sorular sorar; bunların cevabını arar, bilmediklerinin peşini bırakmaz. Bildiklerinin koşullarını, yöntemlerini araştırıp geliştirerek, genel ilkeler ortaya koyup, hem bildiklerini sağlamlaştırmak, hem de bilmediklerini keşfetme yollarını yakalamak için düşüncesini sistemleştirmeye çalışır. ${ }^{2}$ Böylece, bilinmeyen yeni bilgilere ulaşır.

Eğitim sürecinin kökeninde, bilgi, bilgilenme ve öğrenme vardır. Eğitimi, "bilgi edinme" eyleminden soyutlamak mümkün değildir. Buna karşılık, eğitim olayını salt bilgiyle özdeşleştirmek de önemli bir hatadır. Eğitim; temel besinini bilgiden alır, ama onu aşan bir yapılandırıcı, biçimlendirici, davranış değiştirici etkinlik gücüne ulaşır. ${ }^{3}$ Bilgiler, eğitim vasıtasıyla yeniden düzenlenerek insanlara ulaştırılır. Amaç, yeni bilgilere ulaşılmasını sağlamak için zemin hazırlamaktır.

İnsan, bir dizi zihinsel ve duyuşsal faaliyetler sonucu ulaştığı bilgileri, başkalarına da öğretir. Öğretme, değişen ve gelişen bilginin devamlılığını sağlamak için bir gerekliliktir. Belli bir zamana kadar birikip gelen bilgiler, insanlara öğretilerek geliştirilmeyi bekleyen malzeme, onu geliştirecek insanlara iletilmiş olur. Bu anlamda eğitim, öğretme ve öğrenme süreçlerini de içine alır ve onlardan daha geniş bir anlam ifade eder.

Öğretme ve öğrenme süreçleri ise, herhangi bir eğitim faaliyetinin merkez noktasını teşkil ederler. Herhangi bir eğitim faaliyetinin başarısından söz edebilmek için, bir öğretme ve bu öğretmenin sebep olduğu bir öğrenmeden bahs edebilmek gerekir. Yani sonuç ürün olan öğrenme gerçekleşmemişse, bir eğitim faaliyeti yapılmamı̧ demektir. Bir dersin veya bir konunun öğretiminde sağlanacak başarı, aynı zamanda genel olarak eğitimin de başarısıdır.

Ögrretici açısından "öğrenmeyi öğretme", öğrenci açısından da "öğrenmeyi öğrenme”, günümüzdeki eğitim anlayışında nihaî hedef hâline gelmiştir. Öğrenmeyi öğrenmiş bir öğrencinin, yeterliğini keşfetmiş bir birey olarak, bilgiye sürekli ulaşma ve öğrendiği bilgilerden yararlanarak karşılaştığı problemleri çözme kabiliyetini kazanmış olacağı varsayımından hareket edilmektedir. Eğitim anlayışındaki paradigma değişikliği, yani bilgi ve yeteneklerin, öğrenciye ne ölçüde ve nasıl kazandırılacağı noktasındaki hedefler, herhangi bir dersin öğretme ve öğrenme süreçlerinin niteliğine de yansımaktadır.

Ilk ve ortaöğretim ders programlarında zorunlu dersler arasında yerini almış olan Din Kültürü ve Ahlâk Bilgisi dersinin öğretiminde takip edilecek yöntem, teknik ve stratejiler üzerinde, eğitimin genel amaçlarındaki değişikliklerin belirleyici bir etkisi vardır. Yani; şartların ve ihtiyaçların

2 Bilhan, a.g.e., s. 12.

3 Gürsen Topses, Ĕ̆itim Felsefesi Temel Sorunları, Ankara, 1982, Dayanışma Y., s. 151. 
değişmesine paralel olarak, eğitimin genel amaçlarında meydana gelen değişme ve gelişmelerin yönü, din öğretiminin amaçlarında da kendisini hissettirir. O hâlde, "eğitimin genel amaçları, din eğitimi ve öğretimi sürecinin niteliğini doğrudan etkiler" demek mümkündür. Bu etkinin yönünü ve niteliğini tespit edebilmek için, öncelikle genel eğitimdeki paradigma değişikliğinin analiz edilmesi, daha sonra da bu değişikliğin din eğitimiöğretimine yansımalarının neler olabileceğinin tartışılması gerekmektedir. ${ }^{4}$

\section{Eğitimin Genel Amaçları}

Eğitimin, insanı eksiksiz bir yaşam düzeyine götürmeyi, diğer bir deyimle, gerekli tüm ögeleriyle yaşamda bütünlük săglamayı amaçladığı kabul edilmektedir. ${ }^{5}$ Bu amaç, eğitimin "statik" yönüne dikkat çekmektedir. Buna göre, yaşamın tüm ögeleriyle uyumlu bir şekilde hayatını devam ettirmeyi ögrenen birey, huzurlu ve mutlu olabilecektir. Peki, eğitimin amacı sadece bu bütünlüğün sağlanması mı olmalıdır? Eğitimin başka amaçları da var midir?

Hilmi Ziya Ülken, bu soruya şöyle cevap vermektedir:

"Eğitimin vazifesi, değişen kültür şartlarına göre daima yeni intibaklar sağlayacak gençleri değil, fakat değişmelere müsbet bir yön verme gücünde olan gençleri de yetiştirmek olmalıdır. Bu da, eğitimin sadece realist olmak, yani öğrenci-toplum-okul bütünlü̆̆̈̈nü ele almakla kalmayarak, öğrenciideal toplum-okul bütünlüğ̈̈nü de düşünmesiyle mümkün olabilir. Kısaca eğitim, daima ideal bir hedefe sahip olmalıdır. Eğitimin gayesi, ögrenciyi (genci), yalnız hâlihazırdaki topluma intibak ettirmek değil, ideal bir toplum için hazırlamaktır." 6

Bugün eğitimden beklenen çift yönlü bir görev vardır:

1. Toplumun mevcut değer yargılarını ve hukuk düzenini yetişmekte olan nesle tanitip benimsetmek,

2. Onları bu düzene itaatle birlikte yeni değerler üretmeye, benlik geliştirmeye ve topluma yeni seviyeler kazandırmak için çalışmaya yöneltmek?

Her insan, kendisinin de katkıda bulunabileceği bir miras devr alır. Giderek zenginleşen bu mirasın içinde teknoloji, âdetler, gelenekler, değerler, inançlar gibi herşey vardır. Böyle hazır bir ortamda doğan insan, onu alıp benimsemekle ve onu geliştirebilecek faaliyetleri ile, kültürün hem ürünü, hem de yapıcısıdır. Kültür sayesinde yenilenen, gelişen insan,

\footnotetext{
${ }^{4}$ Bu konuda bkz. Beyza Bilgin, Eğitim Bilimi ve Din Eğitimi, Ankara, 1998, Gün Y., s. 67.

${ }^{5}$ Bilhan, a.g.e., s. 37.

${ }^{6}$ Hilmi Ziya Ülken, Eğitim Felsefesi, İstanbul, 1967, M. E. B. Y., s. 37.

${ }^{7}$ Bilgin, a.g.e., s. 17-18.
} 
kültürü yeniler, geliştirir. ${ }^{8}$ Esasen kültür, atalarımızın çeşitli problemleri nasıl çözdüklerini gösteren kayıtlardan başka bir şey değildir.

Her neslin, kendisinden öncekilerden devr aldığı kültüre ilaveler yapmak için faaliyetler göstermesi sosyo-kültürel gelişmenin devamı için zorunludur. ${ }^{9}$ Mevlana; kültürün içerisinde yer alan değerleri, annenin dünyaya getirdiği çocuğa benzetmektedir. ${ }^{10}$ Değerin, yani çocuğun varlığı, annenin kanını süte dönüştürmektedir. Toplumun ihtiyacına göre yeni değerler üretilecektir ki, kültür varlığını devam ettirebilsin. Buradan, değer üretebilen toplumların varlıklarını devam ettirebileceği sonucu çıkmaktadır.

İdeal bir toplumu hazırlayacak gençler, onlara dinamizm kazandırma amacında ve yeterliliğinde olan bir eğitim ortamında yetiştirilebilirler. Böyle bir eğitim ortamı; öğrenmeyi öğrenme, yeni ihtiyaçlara göre yeni bilgiler üretme, problem çözme, yaratıcılık, isabetli düşünme, isabetli karar verme, isabetli davranma, gelecekle ilgili doğru çıkarsamalarda bulunma, yani ufuk ve vizyon sahibi olma gibi zihinsel süreçleri ihtiva eder.

İsabetli düşünme, isabetli davranma, başka bir ifadeyle; etkilere karşı isabetli tepki, insan hayatına yön veren olumlu eylemlerdir. Eğitimin bu yönlendirmeyi yapabilmesi için, zeka, hayal ve hafıza gücünü yükseltici programları, pedagojik yöntemlere uygun olarak gündemde tutması gerekmektedir." Zeka ve eğitimin ilişkiye geçmeleri ölçüsünde, daha doğrusu zekanın eğitim vasıtasıyle işlerliğini artırması ölçüsünde, basiret ve düşünce ürününe dönüşen eylem, diğer canlıların eylemlerinden farklılaşarak tesadüflerin bağımlılı̆̆ından kurtulur. Zekasını kullanabilen insan, süratle öğrenebilen, ögrendiğini yerinde değerlendirebilen, yeni durumlarla karş1laştığında neler yapabileceğini isabetle tayin ederek uygun davranışlar gösteren, problemler karşısında isabetli çözümler bulabilen kişidir. ${ }^{12} \mathrm{O}$, hayatın akışına ve geleceğe olumlu bir yön verebilir.

Eğitim alanındaki gelişmelerle birlikte, artık gelecekte ortaya çıkması muhtemel problemlerin nasıl çözülebileceği konusunda fikir üretebilen gençlerin yetiştirilmesi amaçlanmaktadır. "Gelecekteki Problemleri Çözme Programı" olarak isimlendirilen bu uygulamalarda, ulusal veya küresel ölçekte dinî, sosyo-kültürel, bilimsel veya teknolojik problemler masaya yatırılarak, çözüm için öğrencilerin fikir üretmeleri teşvik edilmektedir. ${ }^{13}$

8 Bcyza Bilgin, “Din Eğitiminin Genel Eğitimdeki Yeri”, A.Ü. llahiyat F.D., c. XXIV, ss. 469-483, s. 469.

${ }^{9}$ Halis Ayhan, Eğitim Bilimine Giriş, İstanbul, 1995, Şule Y., s. 36.

${ }^{10}$ Mevlana, Mesnevî, İstanbul, 1991, Milli Eğitim Bakanlı̆̆ı Y., c. Il., s. 1.

"Bilhan, a.g.e., s. 88.

${ }^{12}$ Ayhan, a.g.e., s. 99.

${ }^{13} \mathrm{Bu}$ konuda bkz. E. Paul Torrance, "Experiences in Developing Technology for Creative Education", Understanding and Recognizing Creativity:The Emergence of a Discipline. New Jersey, 1993, Ablex Publishing Corporation, ss. 158-201, s. 179, 180. 
İnsan hayatının özellikle gençlik dönemi, yukarıda sayılan kabiliyetlerin en çok geliştiği ve daha da geliştirilmeye müsait olduğu bir zaman dilimidir. Genci çocuktan ayıran özellik, onun durumları daha etkin yorumlaması, düşünme, akıl yürütme, yargılama ve genelleme hususlarında olgunlaşmış olmasıdır. Fakat bu olgunlaşma, onların gelişmelerini tamamladıkları anlamına da gelmemektedir. Diğer bir ifadeyle, bu kabiliyetler eğer uygun yöntem ve stratejilerle daha da geliştirilmezlerse körelebilirler. Bu gelişim özellikleri ile ilgili olarak birey şu ihtiyaçları duyar:

1. Yaşama problemlerini kritik düşünme yoluyla halletmek.

2. Olaylardan faydalanarak genellemeler yapma hususunda deneme sahibi olmak.

3. Mantığa uygun düşünmeyi ögrenmek.

4. Düşünme ve davranışa etki yapmak için kullamılan güvenilir ve hatalı teknikleri ayırt edebilmek.

5. Subjektif düşünce ve olaylar arasındaki farkı ayırt edebilmek.

6. Fikirleri mantığa uygun bir yolda sıralamayı öğrenmek.

7. Bir problemin nasıl çözüleceğini öğrenmek.

8. Başkaları ile olan münasebetlerinde rasyonel bir şekilde düşünebilmek.

Görüldügü üzere daha çok zihinsel özelliklerin geliştirilmesiyle ilgili olan bu ihtiyaçlar, aslında insanın hayat serüvenindeki başarısını etkileyecek öneme sahiptirler. Zira, yukarıda sıralanan zihinsel ihtiyaçlarını isabetli bir eğitim programı ile gideremeyen insanın, hayatta başarılı olma şansı oldukça azdır. Çünkü, nasıl düşüneceğini ve nasıl karar verebileceğini, kısaca doğruyu yanlıştan nasıl ayırt edebileceğini bilemeyecektir. Hayat ise, isabetli karar vermeyi gerekli kılan ikilem ve problemlerle doludur. İşte bu noktada eğitime büyük bir görev ve sorumluluk düşmektedir.

Eğitimin Türkiye'deki genel manzarasına bakıldığında ise, bu sorumluluğun ihmal edildiği gerçeği ile karşılaşılmaktadır: Ülkemizdeki gençler hâlâ, hayatın karşılarına çıkarabileceği problemlerle başa çıkabilecek kabiliyet ve donanımla yetiştirilememektedirler. Bu gerçeğin farkında olan Nurettin Topçu, eğitim anlayışımızdaki bu eksikliği şu cümlelerle tesbit eder:

"Tahsili bitirdikten sonra hayata başlamak, elli yaşından sonra dünya hayatının kıymetlerini tanımak, iyi ile kötüyü, haklı ile haksızı, beni ve cemiyetimi yaşatanla çürüteni ayırt etmeğe ellisinde başlamak, filhakika çok acıklı bir hakikattır."14

Elli yaşından sonra hayatın kıymetlerini tanımanın ve iyi ile kötüyü elli yaşından sonra ayırt etmenin sebebi; eğitim vasıtasıyle geliştirilmesi gereken bu kabiliyetlerin inkışafının, deneme ve yanılmalardan ibaret olan acı hayat tecrübelerine, yani tesadüflere bırakılmış olmasıdır: Öğrencilerin, örgün ę̆itime tâbi tutuldukları okul yıllarının, bu anlamda boşa geçirilmesidir.

\footnotetext{
${ }^{14}$ Nurettin Topçu, Türkiye'nin Maarif Davast, İstanbul, 1998, Dergah Y., s. 61.
} 
Yani; beyinlerinin, hayatın anlamın, mutlu ve huzurlu yaşamanın şartlarını hazırlayan, kısaca onlara yaşamayı ögreten bilgilerle değil, kendilerinden sadece ezberlemeleri istenen, yaşanan hayatla ilişkisi olmayan kuru bilgilerle doldurulmasıdır. İlkokuldan lisenin sonuna kadar, ders ve bilgilerin birbirlerinin üzerine yığılması, herbir bilgi ve konunun devamlı tekrar edilmesidir. Zekaya ve problem çözme kabiliyetine işlerlik kazandırmak yerine, bilinen bilgilerin hiç unutulmamasını temin için, öğrencinin sürekli bir ezberciliğe yönlendirilmesidir. Sürekli ezbercilik ise, öğrencinin zihinsel yeteneklerini kemiren bir zehir işlevi görmektedir.

Eğitimi ezbercilikten kurtarabilmek için öncelikle, öğrenilen ve öğretilenlerin insan hayatı içerisinde bir yer, bir bağlantı bulması gerekmektedir. Eğitimin bilim ve mantık temeli kurulduğu andan itibaren, sistem kendi kendisini, yeniler ve canlılığını korur. Fazla bilgi değil, sağlam bilgi insan yaşamıyla bütünleşebilir ve insanı anlamlı bir özne yapar. ${ }^{15}$ Elde edilen bilginin, zekaya işlerlik kazandırması, öğrencideki yetenekleri beceriye dönüştürmesi, bu becerinin bilineni temel alarak, bilinmeyeni keşfetmesi, ondaki gizil güçleri yaratıcılığa geçirmesi, alışılmışın dışındaki yenilikleri merak edebilmesi, eğitimin beklentileri arasındadır.

Yalnız tek bir doğruya bağlı olarak ve mevcut bilgilerden çıkarılan, öğrenciyi bilinen sonuçlara götüren düşünce tarzına, "odaklaşan" süreç denmektedir. Bu düşünce düzeninde öğrenciler, doğru olarak görünen ve öğretmeninin kabul edebileceği sonuçlara ulaşmaya çalışırlar. Odaklaşan sürecin zıddı olan çoğalan düşünceye özgü karakteristik ise, mevcut bilgiye dayanılarak değişik cevap ve sonuçların üretilmesidir. Odaklaşan süreçle düşünen, tek ve belli olan doğru cevabı arar. Çünkü öğretmeni sadece o cevabı istemektedir. Buna karşılık çoğalan düşüncenin cevaplarında çok seçeneklilik, uyumlu esneklik, yorum ve yaklaşımların yeniden ve farklı bir şekilde yapılandırılması, orjinallik gibi özellikler vardır. ${ }^{16}$ Herhangi bir dersin öğretmeni, eğer öğretim süresinden zaman kazanmak için ekseriya yapıldığı gibi, bir tek doğru cevap üzerinde ısrar ederse, öğrenci neticede, kabul edilebilir bir tek doğru cevabı arayan bir ögrenme tarzını benimseyecektir. Birbirinden farklı çözüm yollarının aranmasını teşvik ederse, öğrenci daha çok yaratıcı ve üretici problem çözmeye katkıda bulunan çoğalan düşünme biçimlerini öğrenme eğiliminde olacaktır."

Odaklaşan ve çoğalan düşüncelerle birlikte anılan zihinsel süreçler şunlardır: Odaklaşan düşünceyle birlikte anılanlar: Analitik, tümdengelimsel, kesin (tek doğru), zoraki (baskıc1), biçimsel (şekli). Çoğalan düşünceyle birlikte anılanlar: Tümevarımsal, genişleyen (gelişen), baskıcı olmayan, biçim-

${ }^{15}$ Bilhan, a.g.e., s. 90.

is Alev Arık, Yaratıcılik, Ankara, 1988, Kültür Bakanlığı Y., s. 69-70.

${ }^{17}$ Arık, a.g.e., s. 73. 
sel olmayan, yayılan ve yaratıcı. ${ }^{18}$ Odaklaşan düşüncede sonuç, yani öğrenme ürünü önemlidir. Çoğalan düşüncede ise, düşünme süreci ön plandadır. Başarılı bir şekilde düşünebilen öğrenci, alternatif yollardan hereket ederek farklı sonuçlara kendi başına ulaşabilecektir.

Eğitimin amacı; öğrencileri hür bilimsel düşünceye sahip, olayları eş ve art zamanlı olarak inceleyebilen, görünen sebeplerin dışında da sebep-sonuç arayıp, bulabilen bireyler hâline getirmektir. Bilimsel düşünce, öğrenciyi yalnızca bilgiyle donatan değil; bilgilenme sürecinde öğrenciyi öğretmenin otoritesinden bağımsız, kendi başına düşünmeye, eleştirmeye, yorumlamaya, yani, okuduğunu, söyleneni anlamaya yönlendiren bir eğitimle gerçekleşebilir. ${ }^{19}$ Bilimsel düşünce, öğrencinin alternatif sonuçları bulma, hüküm verme ve tahminde bulunma, bilgi toplama ve tasnif etme, örnek bulma, genelleme yapma, sıralama ve programlama, ölçüt kullanma, bilgiyi sorgulama ve yeniden şekillendirme, etkili bağlantılar kurma ve problem çözme gibi kabiliyetlerinin geliştirilmesini gerektirmektedir. ${ }^{20}$

Ortega Gasset' in ifadesiyle "ilim, kendi ilerleyişinin gerekli düzenleyicisi olarak, yeniden kurulma emeğine ihtiyaç gösterir." ${ }^{21}$ Yeni keşiflere ve sonuçlara, elde edilen bilgilerin yeniden düzenlenmesi ile ulaşılabilir. Ezbere dayalı öğretim sürecinden geçen öğrenciler, ancak o âna kadar elde edilen bilgileri, sırasını bozmadan tekrar edebilirler. Hür bilimsel düşünceye sahip öğrenciler ise, elde edilen bilgileri farklı kombinezonlarda yeniden sıralayıp, bir araya getirerek yeni sonuçlara ulaşırlar.

Geleneksel anlayışa göre, eğitimli kişi; tanımlanmış bir bilgi stokuna sahip bir insandır. Günümüzde ise eğitimli insan; hayat boyu devamlı öğrenmeyi öğrenen, kendisini geliştirmeyi alışkanlık hâline getirmiş kişi anlamına gelmektedir. Eğitim, yeni öğrenme teknolojileri, kuramları ve örgütlenmeleri sayesinde hayat boyu elde edilebilir bir olgudur. Giderek evrenselleşen ve ulaşılabilirliği kolaylaşan bilgiye sahip olmanın yolu, öğrenmeyi öğrenmekten geçmektedir. ${ }^{22} \mathrm{Bu}$ anlamda, ders programlarının içerik ve sunumlarının, öğrenciye bilgi yüklemeyi değil, onların bilgiyi kullanmasını hedef alması beklenmektedir. Başka bir deyişle, dersin içeriğini sunma şekli, öğrencilere bilgiyi ezberlemeyi değil, bilgiyi üretmeyi, yani düşünmeyi öğretmelidir. ${ }^{23}$

Günümüzde her ders için, öğrenmeyi öğretecek öğretim yöntem ve stratejilerine ihtiyaç duyulmaktadır. Aslında 21. yüzyılın bireylerinin, öğrenmeyi öğrenmesi bir zorunluluktur. Çünkü, yaşamak için lehimize

18 Raymond S. Nickerson, The Teaching of Thinking, New Jerscy, 1985, Lawrens Erlbaum Associates, s. 62.

${ }^{19}$ Servet Özdemir, Ĕ̆itimde Örgütsel Yenileşme, Ankara, 1997, Pcgem Y., s. 103.

Nickerson, a.g.e., s. 173.

${ }^{21}$ Ortega Gasset, Kütlelerin Isyanı, çev. Nejat Muallimoğlu, İstanbul, 1992, Bedir Y., s. 94.

22 Özdemir, a.g.e., s. 112.

${ }^{23}$ Yüksel Özden, Eğitimde Dönüşüm, Ankara, 1998, Pegem Y., s. 19. 
çevirmemiz gereken ફ̧artlar, çözmemiz gereken problemler ve öğrenmemiz gereken bilgiler, günden güne hızlı bir şekilde değişmektedir. Dün okulda ögrendiklerimiz, yarın yeterli olmayabilmektedir. Hayatta kalabilmek ve mutlu olabilmek için, kendi başımıza nasıl öğrenebileceğimizi öğrenmeye ihtiyacımız vardır. Bu yüzden, her ders ve konunun nasıl öğrenilebileceğinin, bireylere örgün eğitim vasıtasıyle öğretilmesi büyük bir önem taşımaktadır.

Her öğrenme durumu, bir tür "problem çözme"dir. Kişi, daha önce öğrendiklerini kullanarak, onları "reorganize" ederek problemi çözer. Problemi çözdüğünde, bilmediği yeni bir bilgiye ulaşmış, yani öğrenmiş olur. Bu anlamda öğrenmeyi öğrenme; aynı zamanda problem çözmeyi, karşılaştırma ve genelleme yaparak sonuca gitmeyi öğrenmedir.

Yapılan araştırmalar, çok küçük çocukların bile problem çözme işlemini yaptıklarını göstermiştir. ${ }^{24}$ Çocuklar, yeni deneyimler elde ettikçe, daha zengin bilgiler toplar ve problem çözümü için yeni araçlar keşfederler. ${ }^{25}$ Önemli olan, çocuklara veya genç öğrencilere, daha fazla problem çözme deneyimi yapmalarına imkân verecek bir öğretim süreci yaşatabilmektir.

Geleneksel öğretim tasarımı olarak kabul edilen nesnelci tasarım modelleri, tümdengelimci anlayışa dayahıdırlar. Bu anlayışa göre; belirlenmiş ögretim hedefi, öğrencinin adına öğrenme amacını tanımlar; bu amacı gerçekleştirmek üzere öğrenciye bir dizi bilgi sunulur ve sunulan bu bilginin ne düzeyde edinîldiği değerlendirilir. Örneğin; bir genelleme öğretilirken, nesnelciler öncelikle genellemeyi sunar; ardından bir örnek verir ve değerlendirme aşamasında da farklı bir örneği sunup genellemenin anımsanmasını beklerler. Yapıcı öğrenme yaklaşımları ise; temelde tümevarımsal etkinlikleri kullanmaktadırlar. Öğrencilerin etkin olarak keşfetmelerine dayalı bu tür ögretim faaliyetlerinde, öğrencileri ögrenmesi istenen kural, genelleme, olgu vb. şeyle ilişkili birçok örneği içeren zengin bir bağlam sunulur ve öğrencinin bu deneyim sonunda bir sonuç çıkarması beklenir. Böylece, her öğrenci kendi gerçeğini keşfetmiş olur. ${ }^{26}$

${ }^{24}$ Bu konuda bkz. Stephanie Thornton, Çocuklar Problem Çözüuyor, İstanbul, 1998, Gendaş Y., s. 42.

2s Thornton, a.g.e., s. 47; Öğrenciye problem çözmcyi, yani öğrenmeyi öğrctmenin çeşitli yollan vardır. Bunlardan birisi, öğretmenlerin bu doğrultuda eğitilmeleridir. Bu konuda bkz. Jerome Bruner, Bir Öğretim Kuramına Doğru, çev. Fatma Varıs, Ankara, 1991, A. Ü. Y., s. 130; Öğretmenlerin, doğru karşılaştırma yapma ve problem çözme süreçlerinin kullanılması gerektiğini idrak etmeleri ve bu hususta ögrencilere kılavuzluk yapmaları, öğrencilerin tartışılan herhangi bir konunun anlaşılmasına büyük ölçüde katkıda bulunmalarına yol açar. Bu konuda bkz. Mefharet Ersin, Eğitimde Psikolojinin Rolü. İstanbul, 1981, M. E. B. Y., c. II, s. 303.

26. Cevat Alkan, Ĕ̈itim Teknolojisine Giriş, Ankara, 1985, Önder Matbaacılık, s. 66, 67; Nickerson, a.g.e., s. 10, 118. 
Paulo Freire, öğrenciye problem çözmeyi öğretmeyi hedef alan öğretim yaklaşımına, "problem tanımlayıcı öğretim modeli" adını vermektedir. Bu eğitim modelinde öğretmen ve öğrenciler, hem kendileri, hem de dünya hakkında birlikte düşünürler. Öğrenciler, gerçekliği düşünen "düşünürler" hâline gelirler. ${ }^{27}$ Yapıcı öğrenme yaklaşımlarına dâhil edebileceğimiz problem tanımlayıcı öğretim modelinde, öğrenciyi öğretimin merkezine yerleştiren öğretmenlerin önemli bir fonksiyonu vardır. Onların görevi, gerekli bilgileri bulmak, problemi yorumlayarak analiz etmek ve farkli düşünme yollarını bulmak için öğrenciye yardım etmektir. ${ }^{28}$

Problem tanımlayıcı ögretim modelinde, sadece programdaki konularla yetinilmez. Öğrenci, karşılaştığı herhangi bir güncel problemi sınıf ortamına taşıyarak, çözümü konusunda öğretmeninden yardım isteyebilir. Hatta sınıfta ögretmen ve bütün ögrencilerin katılımıyla bir "beyin fırtınası" da gerçekleştirilebilir. Mesela; bu doğrultuda dergi yazıları, gazeteler ve kitap bölümleri sınıfta okunarak tartışılabilir. Gazete baş yazılarının muhtevası analiz edilebilir. "Niçin aynı olayı, değişik gazeteler farklı yorumluyorlar?" sorusuyla, farklı yaklaşımların ardındaki nedenler üzerinde durulabilir. ${ }^{29}$

Öğrencinin, devamlı olarak "nedir”? Bu konu hakkında ne biliniyor, ne söylenebilir? Eğer...ise ne olur? gibi soruların cevabını araştırması sağlanabilir. Yine devamlı olarak, "daha başka? Bu olay bundan başka nasıl yorumlanabilir? Bu olaydan hangi sonuç çıkartılabilir?" sorularının cevabını bulmak için derin araştırmalar yapmaları temin edilebilir. Öğrenci, hedefe farklı yollardan varmayı denemeli ve buna teşvik edilmelidir. Öğretmen, öğrenciye doğru cevabı vermek veya olayı değerlendirmek yerine, onu düşünmeye sevkederek, problem çözme sürecini öğrenmesini sağlamalıdır. Böylece ögrrenci, bir olayın farklı bakış açılarıyla nasıl yorumlanabileceğini tecrübe etmiş olur. Yorumlar arasındaki benzerlik ve zıtlıklardan yola çıkıp karşılaştırmalar yaparak, yeni bir "sentez"e ulaşmayı dener. Düşünme gücünden yararlanmayı öğrendiğinde, öğretim süreci amacına ulaşmış demektir.

\section{Eğitimin Genel Amaçları Açısından}

\section{Din Kültürü ve Ahlâk Bilgisi Dersleri}

Görüldüğü üzere günümüzün eğitim-öğretim anlayışı (paradigması), yapıcı yaklaşım yönünde değişme ve gelişme göstermektedir. Bu yeni anlayışa paralel olarak, bilgileri ezberletmeye dayalı öğretim yöntem ve teknikleri terkedilmektedir. Öğrenciyi merkeze alan öğretim sürecinin hedef davranışları artık, kavrama, açıklama, uygulama ve problem çözme gibi zihinsel faaliyetlerdir. Hazır bilgilerin pasif bir alıcısı olmak yerine, aktif bir

\footnotetext{
27 Paulo Freire, Ezilenlerin Pedagojisi, çev. Dilek Hattatoğlu, İstanbul, 1998, Ayrıntı Y., s. 62.

${ }^{28}$ Servet Özdemir, Her Yönüyle Ö̆rretmenlik Mesleği, Ankara, 1998, Nobel Y., s. 40.

By Bk. Freire, a.g.e., s. 100-101.
} 
şekilde öğrenmeyi öğrenen öğrenciden, sürekli yeni bilgilere ulaşması, yeni sentezler yapması, başka bir ifadeyle sürekli bilgi üretmesi beklenmektedir. Herhangi bir ders, ögrencideki bu kabiliyetleri harekete geçirmekle sorumludur.

İlkögretim ve liselerin programlarındaki Din Kültürü ve Ahlâk Bilgisi dersleri vasıtasıyle yapılmakta olan din eğitimi de, bu sorumlulukla karşı karşıyadır. Bir fizik öğretmeni nasıl ögrencilerinden, elektrikle ilgili temel olguları ögrenmelerini ve bu olguları kullanarak laboratuvarda elektrik üreten küçük bir tesis kurmaların isterse, DKAB dersi ögretmeni de, temel olguları öğrettikten sonra; öğrencilerinden dinî konularda problem çözmelerini, tavır ve tutum geliştirmelerini, insanlarla iletişim kurarken dinî duygu ve düşüncelerden etkin bir şekilde yararlanmalarını isteyebilmelidir. Tabii ki öğrenciden sadece bunları istemek yetmez. Ona, din dersinin laboratuvarı olan toplumda, dinî bilgileri nasıl kullanabileceklerini öğretmek gerekmektedir. Yani bilgileri öğrencinin yaşadığı hayatla bağlantılar kurabileceği şekilde öğretim konusu yapmak icap etmektedir.

$\mathrm{Bu}$ anlamda din öğretimi de, eğitimin genel amaçları doğrultusundaki davranışları öğrenciye kazandırmak durumundadır. Öğrenci, dinî öğrenirken, aynı zamanda yukarıda geçen zihinsel kabiliyetlerini de geliştirebilmelidir. Dinî bilgiler, öğrenciye öyle bir yaklaşım ve yöntemle verilmelidir ki, zihinsel kabiliyetleri harekete geçen öğrenci, öğrendiklerini kullanarak öğrenmediklerine de ulaşabilmelidir. Bir ders süresi içinde veya ilköğretim dördüncü sınıftan lise üçe kadar devam eden Din Kültürü ve Ahlâk Bilgisi ders programı boyunca, öğrenciye dinî konudaki bütün bilgileri ulaştırmak mümkün değildir. Mümkün olsa bile, hayatın karşımıza çıkardığı dinî içerikli problemler sürekli değişmektedir. O yüzden, öğrenciye bu problemleri dinîn formuna aykırı olmadan, yani doğru bir şekilde nasıl çözeceğini öğretmek gerekmektedir.

Öğrenci, öğrendiği bilgileri açıklayabilmeli, inandığı ya da bildiği bir şeyin neden ve niçin öyle olduğunu izah edebilmelidir. Kendi gayretinin bir ürünü olarak; hangi davranışın doğru, hangi davranışın yanlış oldugunu ayırt edebilecek bir ölçüt geliştirebilmelidir. Bunun için, dinî duygu, düşünce ve davranışların altında yatan temel espriyi öğrenciye kavratmak gerekmektedir. Kavrama süreci sonucunda öğrenci, bağımsız bir şekilde, yani; başkalarına ihtiyaç duymadan, kendi başına düşünebilecektir. Kendi başına düşünmeyi öğrenen insan, pekçok kabiliyetini kullanmak zorundadır. Olguları tanıma, akıl yürütme, kavram oluşturma, genelleme ve sentez yapma, değerlendirme gibi kabiliyetler, düşünen bir zihnin geçirdiği süreçlerin adıdır. ${ }^{30}$

${ }^{30}$ Mualla Selçuk, "Din Öğretimi Özgürleştiren Bir Sürę̧ Olabilir mi?", Islamiyat Dergisi, S. 1., ss. 73-87., s. 78 . 
Bir çok tecrübe göstermiştir ki, öğrenciye çok şey ezberletmek ve çok nasihat etmekten ziyade, onları düşünmeye alıştırmak daha verimli olmaktadır. Düşünmeye alışan insan, kendisine öğretilmek istenen bir çok şeyi, düşünme gücüyle bulacaktır. Düşünülerek elde edilen bilgi ve hakikatler, bir emek mahsulü olduğundan dolayı hafizada uzun süre kalmaktadır. ${ }^{31}$ Öğrencinin istediğimiz yönde davranı̧ kazanması da daha kolay olmaktadır. Çoğu zaman düşünce ile bilgi birbirinin zıddı imiş gibi anlaşılmıştır. Halbuki her ikisi de eğitimde gereklidir. Özellikle, davranış, tavır ve tutum geliştirmenin önemli hedefler arasında yer aldığı din öğretiminde, düşünme ve kavrama vazgeçilmez zihinsel süreçlerdir. Öğrenci, hayatın içindeki yerini ve önemini kavrayamadığı bir davranışı, geliştirmek (gerçekleştirmek) için nasıl istekli olabilir?

Mesela; öğrenciye "ibadet" kavramı ögretilmek ve ibadet etme davranışı benimsetilmek istenmektedir. Bu konuda çoğu zaman baş vurulan yöntemlerden birisi; namazın rükünleri ve kılınışı ile birlikte, ibadet etme eyleminin insan için bir "zorunluluk" olduğunu onlara öğretmektir. Öğrencilere, "bu dünyada ibadet etmeyen insanların ahirette cezalandırılacakları" haber verilerek, onların ibadet etme davranışını benimseyecekleri beklenir. Burada, eğitimin genel amaçlarına uygunluk açısından sorulacak soru şudur: Acaba, bu tarzdaki bir öğretim sürecinde, insanın niçin ibadet etmesi gerektiği, ibadet etmenin Allah-insan ilişkisi açısından ne anlam ifade ettiği üzerinde durulmakta mıdır? Yani; öğrenciye benimsetmek istediğimiz davranış, onun duygu ve düşünce dünyasında anlamlandırılmakta mıdır? Öğrencinin düşünme, kavrama, uygulama, analiz-sentez yapma ve değerlendirme yetenekleri öğretim süreci boyunca harekete geçirilmekte midir?

Ögrenciye ibadet etme davranışı, yapılmadığı takdirde karşıllaşılacak cezâi müeyyideler akla getirilip, ondaki korku ve endişe duyguları harekete geçirilerek mi, kazandırılmak istenmektedir? Yoksa Allah'ın insanlara verdiği değer, onlara bahşettiği türlü nimetler gibi, hayatın içinde bire bir ilişkiye geçebileceği olgu ve olaylar aklına getirilip, şükran ve saygı duyguları harekete geçirilerek mi ibadet etme isteği uyandırılmak istenmektedir? Öğrencinin gelişen şahsiyeti, hayatı boyunca elde ettiği deneyimler ve hür iradesi hesaba katılarak mı, yoksa göz ardı edilerek mi dinî duygu, düşünce ve davranışlar ona kazandırılmak istenmektedir?

Bu soruya Nurettin Topçu şöyle cevap vermektedir:

Beden, el, ayak, diz, dirsek hareketleriyle Allah'in sevgisini kazanarak ebedî sadete ulaşılaca $\breve{g} ı$, durmadan halka telkin edildiğinden Müslüman cemiyetinin ruh dünyası, sadece işlenmemiş olarak kalmadt, saydı̆̆ımız beden hareketlerinin yanında değersiz, önemsiz ve manasız bir boşluğa dönüştürülmüs oldu. Ibadet esnasındaki Allah'ı düsünme ve O'na yakınlaşma, sırf hayal gücünün fantezisine bağland. Insanlar, dinî davrantşlarında ken-

31 Faruk Bayraktar, Isslam Ĕ̆itiminde Ö̆gretmen-Ö̆̆renci Münasebetleri, Istanbul, 1989, IFAV Y., s. 199. 
dilerini, polis karakolunda dayak yemeye hazırlanan suçlunun korkusuna sun'i bir zorlayışla sokmaktan başka bir şey yapmadılar." ${ }^{32}$

Topçu'nun da ifade ettiği gibi, örgün ve yaygın din öğretiminde yaptığımız hatalardan en önemlisi, öğrencilere dinî, matematiksel bir mantıkla benimsetmeye çalışmamızdır. "Şu davranı̧̧ları yaparsan, şu sonuçlarla karşılaşırsın. Bu davranışları yaparsan, bu sonuçlarla karşılaşırsın”" şeklindeki bir anlayışla öğrenciye yaklaşmamızdır. Bu şekildeki bir yaklaşımla öğrencideki cezalandırılma korku ve endişesinin galip geleceği, sonuç olarak da öğrencinin bizim istediğimiz davranışları yapmayı tercih edeceği hesab edilmektedir. İbadet kullanma veya etmeme ile cezalandırılma veya mükafatlandırılma arasında, çok basit bir ilişki kurulmaktadır. Allah'ın emirlerine uyulmadığı, yasaklarının çiğnendiği takdirde bir cezalandırma ile karşılaşılabileceği, şüphesiz Kur'ân'da da ifade edilmektedir. ${ }^{33}$ Ancak Kur'ân'da Allah, insanda ibadet etme arzusu ve şevki uyandıracak şekilde Kendisi'ni ve insanlara olan inayet ve rahmetini de anlatmaktadır. ${ }^{34}$

Kur'ân'da, dünya ile ahiret arasında çok basit bir sebep-sonuç ilişkisi kurulmamaktadır. Yani Allah, kullarını sadece; "şu şu davranışları yaparsanız Cennet'e, şu şu davranışları da yaparsanız Cehennem'e gidersiniz" gibi "ya o, ya da bu" şeklinde bir tercihle karşı karşıya bırakmamaktadır. İnsana, düşünme ve irade etme niteliklerini veren Allah, çoğu zaman onun bu niteliklerine hitap etmektedir: "Düşünmüyor musunuz?", "akletmiyor musunuz?" gibi. ${ }^{35}$ Allah, Kur'ân'da insanlara bilmedikleri konuları, düşünüp anlasınlar diye açıklamaktadır. Allah'ın yarattığı şeyler üzerinde düşünmek, onları incelemek, insanı Yaratan'ın Birliğine, Kudret, Hikmet ve Rahmetine götürür. ${ }^{36}$ Doğru bir Allah tasavvuruna sahip olması temin edilebilirse, ögrenci zaten Allah'a duygusal bir yakınlık hissedecektir. Duygusal yakınlığı, davranışsal yakınlığa, yani ibadetlere dönüştürmek kolay olacaktır.

Öğrenci tarafından Allah, sürekli kusur arayan bir varlık olarak düşünülürse, bunun çeşitli mahzurları olabilir. Sürekli suç ve ceza peşinde koşan, tehdit edici, her zaman sertliği ön planda tutan bir Allah tasavvuru, ögrencinin O'nu yanlış ve eksik tanımasına neden olabilir. Şayet dinîn yasakladığı bir fiilin "kötü olduğunu ve cezalandırılmayı hak ettiğini" öğretmek istiyorsak, öğrencinin o fiile tepki gösteren bir insan hâline getirilmesi önemlidir. İşlenen bir suça verilecek cezanın, adil bir davranı̧ olduğunu, öğrenciye kavratmak lazımdır. Bazı insanların, tehdit ve korkutma karşısında suçtan caydırılabileceği bir gerçektir. Ancak, Allah'ın sadece

${ }^{32}$ Topçu, Türkiye'nin Maarif Davast, s. 156.

${ }^{33}$ En'am, 6/157; Maide, 5/98.

${ }^{34}$ Bu konuda bkz. Mehmet Emin Ay, Din Eğitiminde Mükafat ve Ceza, İzmir, 1994, Nil Y.. 59-64.

${ }^{35}$ Bkz. Zariyat, 51/21;

3h Mehmet Aydın, "Ilim-İslam Münasebeti", Bilgi, Bilim ve Islam l, İstanbul, 1992, ISAV Y., ss. $65-84$, s. 81 . 
korkutucu ve ceza verici bir Yaratıcı olarak tanıtılması da doğru değildir. Bu, O'nun bir yönüdür. Öğrencinin sürekli böyle bir telkine tabi tutulması, onu psikolojik olarak olumsuz etkileyebilir. Hayatının ve beklentilerinin akışına engel olan Allah tasavvurundan öğrenci, soğuyabilir ve uzaklaşmak isteyebilir. Yanlış bir anlayış ile bozulmuş zihinlerin, başka bir deyişle; sağlıklı beslenmeyen gönüllerin, Allah ile barıştırılması, zamanla bir mesele hâline bile gelebilir. ${ }^{37}$ Allah'ı cezalandıran, azap veren biri olarak tanıtmak İslam eğitim anlayışına ters düşmektedir. Kullarını seven ve onlara sayılamayacak kadar nimetler veren Allah'ı, öğrencinin zihninde, kızan, ceza ve azap veren biri olarak şekillendirmek doğru değildir. ${ }^{38}$

Kur'ân'da Allah, kendisini insana doksan dokuz ismi ile tanıtmaktadır. Halbuki, insana kendisinin mücerred ve aşkın bir varlık olduğunu haber verip, ondan kayıtsız şartsız iman ve itaat isteyebilirdi. Böyle yapmamıştır. Evrendeki çok çeşitli olgu ve olayları anlatarak, insanı kendi varlığı ve doksan dokuz isminin tecellileri üzerinde düşündürmek istemiştir. Kur’ân'da birbirinden farklı imiş gibi görünen pek çok anlatımda, insana yönelik bir "kavratma, izah etme" iradesi görülebilmektedir. ${ }^{39}$ Düşünen bir varlık olan insandan, Yaratıcısının kendine olan inayet ve yakınlığını farketmesi beklenmektedir. ${ }^{40}$ Yine Kur'ân'da Allah, insana lutfettiği nimetleri anlatmaktadır. ${ }^{41}$ Buradaki maksadın, nimetlerin hepsini saymak olmadığı, izaha gerek duyulmayacak kadar açıktır. Zaten Allah, nimetlerinin sayılamayacak kadar çok olduğunu başka ayetlerde ifade etmektedir. Pek çok ayette, Allah-insan ilişkisinin sevgi bağlamında ele alınmış olması da ${ }^{42}$ dikkate alınacak olursa, Allah' In insanları Kendi sevgisini kazanmaya doğru yönlendirdiği görülebilmektedir.

Allah, insanın kendi iç âlemi hakkında da düşünmesini istemektedir. "Kendi nefisleri hakkında düşünmediler mi?"43 ayetinde bu istek dile getirilmektedir. İnsanın kendisi hakkında düşündükten sonra, dış âlemin yaratılış keyfiyyetini ve Yaratıcısı'nı tanıması daha kolay olacaktır. Böylece Yüce Allah, düşünceyi insanın kendi iç âleminden başlatarak, dış âleme oradan da ahirete yöneltmektedir. İnsan, iç âlemindeki oluşumlar üzerinde düşünüp, oradaki fırtınaların şiddetini, yönünü ve ağırlığını tanıyınca, dış âlemi ve ahireti daha iyi anlayacak ve imana ulaşacaktır. Bu iman, bir

\footnotetext{
${ }^{37}$ Kerim Yavuz, Günümüzde Din Eğitimi, Adana, 1998, Çukurova Ü., İlahiyat F. Y., s. 216.

38 Mehmet Emin Ay, Çocuklarımiza Allah't Nasıl Anlatalım, Ankara, 1987, s. 106.

${ }^{39}$ Bkz. Al-i Imran, 3/190-91., Ra'd, 13/3-4., Ğaşiyc, 88/17-29.

4n Bu konuda bkz. Gazalî, el-Hikmetü fi Mahlukati'llahi Azze ve Celle, İstanbul, 1971, Dede Korkut Y.; Cafer Sadık Yaran, Tanrı Inancının Akliliği, Samsun, 2000, Etüt Y. s. 48.

${ }^{41}$ Bkz. Rahman, 55.

42 Bkz. Bakara, 2/222.

${ }^{43}$ Rum, 30/8.
} 
dayatma ile veya dışarıdan bir etkiyle değil, insanın kendi düşüncesinin bir ürünü olarak oluşmaktadır. ${ }^{44}$

Kur'ân'da, insanın hür iradesiyle Allah'a ibadet ve itaat etme şuuru uyandırılmak istenmektedir. Zaten İslâm Dinî'ne göre, hür olmayan birinin yaptığ maruz kalmadan, kendi iradesiyle Allah'a teveccüh göstermelidir. "Dinîn vaz edilişinin gerçek amacı; insanı zorunlu kulluktan çıkarıp, kendi serbest seçimine dayalı kulluğa yïkseltmektir.",45

O halde, ibadet öğretimi yapılırken Kur'ân'daki bu yaklaşım esas alınabilir. Yani; bir nevi ibadet fenomenolojisi yapılabilir. İbadet fenomenolojisi; ibadetin özünü açıklamak için, tüm olguları, yani ibadetin ibadet olması için yerine getirilmesi gerekli şekil, şart ve rükünleri; dinîn genel prensipleri ve gayesini de göz önünde bılundurarak anlamlandırmaktır. ${ }^{46}$

Peki bu nasıl olacaktır? Öncelikle öğrencinin, Allah'ı çok iyi tanıması sağlanabilir. Çünkü, bütün ibadetlerin ilk ve son gayesi; insanı Allah'ın huzuruna götürmektir. Din Kültürü ve Ahlâk Bilgisi dersinde, Kur'ân'daki İlahî beyanın rehberliğinde, öğretmenin de yardımıyla, Allah'ın evrendeki varlığı ve birliğinin tecellilerini görüp, onlar üzerinde düşünerek, sağlam bir Allah inancı ve tasavvuruna sahip olması mümkündür. Eşya ve olaylar üzerinde düşünerek, kendi zihinsel çabasının ürünü olan tahkikî bir inanca ulaşması Allah'ın da iradesine uygundur. "Marifetullah" adını verdiğimiz bu bilgiyle, Allah'a yakınlık ve muhabbet duymaya başlayan öğrenci, O'na karşı birşeyler yapmanın isteğini, yapmıyorsa yapmamanın ezikliğini hissedecektir. Yoksa, sadece namazın içindeki ve dışındaki farzları, namaz sure, dua ve rükünlerini ezberleyen, namaz kılmadığı takdirde çarptırılacağı cezaları düşünerek, derin bir korku içinde namaz kılan bir öğrenci, ibadet etmenin ruhunda var olan Allah-insan ilişkisindeki güzelliği hissedemeyecektir. Allah'a, gönül dünyasında hissettiği aşk ve şevkle ibadet etmediği için, insanlarla olan ilişkilerinde de müsbet bir gelişme muhtemelen olmayacaktır. Çünkü, zorla yapılan ibadet, öğrencinin gelişmekte olan kişilik ve karakter yapısı üzerinde baskı kurduğu için, onun ahlâkını değiştiremeyecek, hatta öğrenci, zamanla dinî şüphe ve buhranlara kadar varabilecek "iç çatışmalar" yaşayabilecektir. Bunun nedeni, inancı ile düşünce ve bilinci arasındaki gerekli bütünlügün sağlanamamış olmasıdır. Din Kültürüu ve Ahlâk Bilgisi dersi ögretmeninin görevi, bu bütünlüğü sağlayacak yöntem, teknik ve stratejileri uygulayarak, öğrenciye rehberlik etmektir.

44 Bayraktar Bayraklı, Mukayeseli Egitim Felsefesi Sistemleri, Istanbul, 1999. IFAV Y., s. 231.

${ }^{45}$ Selçuk, a.g.m., s. 80.

46 Mehmet Bayraktar, Islam Ibadet Fenomenolojisi, Ankara, 1987, Akçağ Y., s. 5; Bu konuda bkz. Ruhi Özcan, Ibadetlerde Şekil ve Mana Ilişkisi, Erzurum, 1986, Ravza Y., s. 31-64. 
Yukarıda yapılan değerlendirmelerden hareketle, Ramazan Buyrukçu'nun şu tesbitlerine katılmamak mümkün değildir:

"Din eğitimi ve öğretimini, emir ve yasakların ezberletilmesi şeklinde anlamak ve uygulamaktan kurtaracak zihniyetin oluşmast ve yaygınlaşması gerekmektedir. Çünkü, böyle bir anlayış, dinîn kişilik gelişimi üzerindeki etkisini azaltmaktadır. Halbuki din eğitiminin görev ve amaçlarından birisi ve en önemlisi, insana kişilik ve karakter kazandırmaktır. Şüphesiz, dinîn ilke ve prensipleri, emir ve yasaklar, inanç esaslar, ibadet şekilleri ve ahlâkî kuralları, din eğitimi programlarında yer alacaktır ve almalıdır. Ancak bu prensipler, insanın gelişim özelliklerine göre işlenirse bir anlam kazantr. Inanç esaslarınt, zihnen ve ruhen anlamayan ve yorumlayamayan insanın imant taklidî, ibadet ve ahlaki kuralları yerine getirmesi, örîi olacaktır."47

$\mathrm{Bu}$ durumda da, insanla Allah arasındaki metafizik bir ilişkiden doğacak ve "kutsal" bir değer ifade edecek olan; "ibadet" adını verdiğimiz davranışlar, sadece "alışkanlıkların" yerine getirilmesinden ibaret kalacaktır. İbadetin sadece bir alışkanlık olarak yerine getirilip, insan ahlâkına olumlu manada yön vermemesi, bizzat Kur'an tarafından eleştirilmektedir. ${ }^{48}$ Kur'an1 Kerim, namazı insan davranışlarını olumlu yönde etkileyen ${ }^{49}$ ve kalpleri huzura kavuşturan ${ }^{50}$ bir ibadet olarak tarif etmektedir.

Alışkanlıklar, eğitim vasıtasıyle insanda geliştirilmesi gereken karakter hakkında bize sağlam bir bilgi vermez. "Bazı faydalı alışkanlıklardan meydana gelen hareketler, yıllarca aynı tarzda yapılsa dahi, hakiki karakterin insanı aldatmayan bir tasviri sayılamaz. Zira iç ilgi ve ihtiyaçlardan ziyade, zorlama ile meydana gelen alışkanlık hareketleri, ileride yavaş yavaş hiç yapılmayabilir. Hatta araya öyle hadiseler girer ki, alışkanlık sonucu meydana gelen hareketlerin yapılması beklenirken, bunların yerine tamamen aksi hareketlerin yapıldı̆̆ı da görülebilir."sı

Kerschensteiner, böyle bir sonuçla karşılaşılmasının nedenini şu şekilde izah etmektedir:

"Öyle ögrretim yöntemleri vardır ki, ikinci çocukluk ve gençlik dönemine kadar, dış ve mutlak itaati devam ettirmekte, öğrencinin hareket hürriyetini son derece zorlaştırmakta ve durmadan ahlâkî ve dinî talepleri zorla kabul ettirmeye çalışmaktadır. Bu öğretim tarzı, bir çok çocuğun, özellikle sert kişiliklerin hakiki karakter gelişimini köstekler. Zekayı kurban

${ }^{47}$ Ramazan Buyrukçu, "Ortaokullardaki Din Kültürü ve Ahlak Bilgisi Öğretimine Genel Bir Yaklaşım, Dini Araştırmalar D., c. 2., S. 4., 177-195., s. 189.

44 Maun, 107/4-7.

49 Ankebut, $29 / 45$.

so $\mathrm{Ra}$ 'd, 13/28.

${ }^{51}$ Kerschensteiner G., Karakter Kavramı ve Terbiyesi, çev. Fikret Kanad, Ankara, 1977, M. E. B. Y., s. 16. 
ederek, Allah vergisi aklı kullanmaktan vaz geçme bahasına talep edilen bir haricî itaat, yalnız karakterin belkemiğini kırmakla kalmaz, haricî tesiri bakımından karakterin sevimli ve kıymetli cephesi de felce uğratılmıs olur." 52

Öğrenci, her konuda olduğu gibi, dinî konularda da isabetli düşünebilmeli ve isabetli karar verebilmelidir. En önemlisi ise, daha sonra içinden çıkılmaz hâle gelebilecek problemlere yol açan yanlış düşünce ve davranışlardan uzak kalabilmelidir. Daha doğrusu, yanlış düşünce ve davranışları, doğrularından ayırt etmeyi öğrenmiş olmalıdır. Bu, bir tür "dinî bilinç" kazanmadır. Aslında, herhangi bir davranışın anlam kazanabilmesi için, onun bilinçli bir şekilde yapılması gereği, İslâm Dini'nin de istediği bir şeydir. İslâm Dini, cahilce yapılan davranışları eleştirir. Hatta İslam'a göre, "inanmama"nın sebeplerinden en önemlisi, bilgisizlik ve bilinçsizliktir. Kur'ân'ın pek çok yerinde Allah inanmayanları, akl etmemek, düşünmemek, ibret almamak ve cahillikle suçlamaktadır. ${ }^{53}$ İnanmak için, belli bir bilgi birikimine sahip olmak ve evrene araştırıcı bir gözle bakmak gerekmektedir. ${ }^{54}$

İşte bu yüzden, öğrencilere dinî bilgileri öğretirken, onların zeka, düşünme, kavrama, karşılaştırma yapma, bir senteze ulaşma gibi melekelerini işe koşmak gerekmektedir. "Hatta Din Kültürü ve Ahlâk Bilgisi dersleri, bir bakıma "düşünme ve düşünmeyi öğrenme" dersleri hâline getirilebilir. Düşünme veya başka bir deyişle akıl yürütme, neden ve niçinlere ulaşmanın biricik yoludur. "Düşünme, eşya ve olaylar arasındaki gizli münasebetleri anlamaya, onların uzak ve yakın sebeplerini ortaya çıkarmaya, muhtemel neticeleri tahmin etmeye ve geleceğe yönelik hükümler vermeye yarar." 55 "Bu derslerde, düşünme ya da zihinsel arayışa geçme yolu açlıp, oradan çözüme ulaşılabilir. Din eğitimi-öğretiminde, öğrencinin dine zihnen iyice nüfuz etmesi ve onun özünü yakalaması bakımından, akla işlerlik kazandırma lüzumu vardır." ${ }^{\text {"6 }}$ Böylece, hem eğitimin genel amaçları, hem de İslâm Dinî'nin isteği doğrultusunda hareket edilmiş olacaktır: Öğrenci, inancını akıl ve bilgi zemininde temellendirerek, sağlam bir karakter ve kişilik yapısına, istenen bir ahlâka sahip olabilecektir.

Din Kültürü ve Ahlâk Bilgisi derslerinde dinî konularda bilgilenen öğrenciler, zaman zaman inançlarını sarsabilecek fikir ve olaylarla karşılaşabilmektedirler. Mesela; Din Kültürü ve Ahlâk Bilgisi derslerinde, Peygamberlere iman ve $\mathrm{Hz}$. Muhammed'in Peygamberliği gibi konuları öğrenen

\footnotetext{
\$2 Kerschensteiner, a.g.e., s. 97.

${ }^{53}$ Enfal, 8/22; A'raf, 7/179; Bakara, 2/171.

ss Bu konuda bkz. Ramazan el-Buti, Kur'an Eğitiminin Eşsiz. Metodu, İstanbul, 1987, Madve Y., s. 23-24.

ss Faruk Bayraktar, "Eğitimin En Önemli Hedefi Düşünmek ve Düşünmeyi Öğretmek", Din Öğretimi D., S. 28., ss. 16-20, s. 16.

s6 Yavuz, a.g.e., s. 217
} 
öğrenciler, çeşitli yayınlar vasıtasıyla da Peygamberlik müessesesinin varlığı ve $\mathrm{Hz}$. Muhammed'in Peygamberliği hakkında şüphe duymalarına sebep olabilecek fikirlerden haberdar olabilmektedirler. ${ }^{57}$

Farklı inanç ve düşüncelere sahip kişilerin varlığı, öğrenciyi kendi inanç ve değerlerini yakından incelemeye zorlar. $\mathrm{O}$ ana kadar, hiçbir tenkide tâbi tutmaksızın benimsemiş olduğu dinî inanç ve uygulamalar, öğrenci tarafından sıkı bir şekilde gözden geçirilir. Özellikle ergenlik dönemindeki öğrenciler, zihnî bakımdan bütünleşmiş benliklerinin farkına vardıklarından dolayı, hayatın sentezini tenkitçi bir şekilde yaparlar. Dinî inançların anlamını ve dinî gerçeklerin mahiyetini de zihinsel olarak anlamak ve bunları yaşanan hayatla bağdaştırmak isterler. ${ }^{58}$

Öğrencinin hayatından bağımsız olarak öğrenilen bilgilerle, hayatın gerçekliklerinin örtüşmediği durumlarda, üzerinde düşünülmeksizin ezberlenilen bilgilerin öğrenciyi sıkıntıya düşürebileceğini dikkate almak gerekmektedir. Böyle durumlarda öğrenci, derste ögrendikleri ile, hayatında karşılaştığı bilgileri bağdaştıramamakta ve bir tercih yapmak zorunda kalmaktadır. ${ }^{59}$

Din Kültürü ve Ahlâk Bilgisi derslerinde öğrendikleri bilgilerle çatışan bu fikirler üzerinde düşünüp, önceki bilgilerini ve inançlarını doğrulayacak bir sonuca ulaşamadıklarında ise, inandıkları şeylerden şüphe duyabilmektedirler. $^{60}$

Bu durum, önemli ve çözülmesi gereken bir problem hâlidir. Fakat daha da önemli olan; öğrencilerin, karşılaştıkları bu problemi çözmelerine yardım edecek düşünme, karşılaştırma yapma, olayları yorumlama, genelleme yapma ve nihayet problemi çözme egzersizinden geçip-geçmemiş olduklarıdır. Eğer, DKAB derslerinde öğrencilere, karşılaş̧tıkları bu tür problemleri kolaylıkla çözebilmelerine imkân verecek kabiliyet kazandırılmışsa, yani onlara ögrenmeleri öğretilmişse, onlar kısa bir sürede bu işin içinden çıkacaklardır. Aksi durumda ise, ya birine gidip doğrunun ne olduğunu soracaklardır; ya da zamanla onların zihninde girdap hâline gelecek olan bu durum, onların dinî inançlarını yutabilecektir.

Mesela; öğrencilere hem ilköğretim, hem de ortaöğretim DKAB ders programında Hz. Peygamber'in hayatı yer almaktadır. Burada konumuz açısından şu soruyu sormak gerekmektedir: $\mathrm{Hz}$. Peygamber'in hayatı nasıl ögretilmektedir? Hz. Peygamber'in hayatı öğrencilere sadece kronolojik bir sırayla, yani olay, yer ve tarih gösterme şeklinde öğretilmişse; ezberlenen bu bilgiler, öğrenciye bu problemi çözme konusunda yardım etmeyecektir.

${ }^{57}$ Mesela; Turan Dursun'un "Din Bu” adlı kitaplarında bu tür iddialara rastlanmaktadır. Bkz.

Turan Dursun, Tabu Can Çekişiyor Din Bu, İstanbul, 1992, Kaynak Y.; Ayrica bkz.

Erdoğan Aydın, Islamiyet Gerçeği, Istanbul, 1993, Kaynak Y.

${ }^{58}$ Hayati Hökelekli, Din Psikolojisi, Ankara, 1993, Türkiye Diyanet V. Y., s. 271.

${ }^{59}$ Cemal Tosun, Din Eğitimi Bilimine Giriş, Ankara, 2001, Pegem Y., s. 158, 159.

a) Bkz. Hökelekli, a.g.e., s. 270-273. 
Şüphesiz ögrenci, önemli olayların geçtiği tarih ve yerleri bilecektir; fakat eğitimin genel amaçları anlatılırken de değinildiği üzere; bu kuru bilgiyle, inancını devam ettirme ve savunmasını yapma konusunda yetersiz kalabilecektir. Çünkü $o$, henüz inandığı değerlerin açıklamasını kendi kendisine ve başkalarına yapamamaktadır. Inancı, zihinsel olmaktan çok taklit ve itaat seviyesindedir. Zihnine istif edilmiş bilgileri bir araya getirip, farkh kombinezonlar üreterek, yeni genellemelere ulaşamamaktadır. Dolayısıyle, DKAB dersi imtihanlarında sorulan sorulardan farklı bir soru ile karşılaştığında mantıklı bir cevap bulamamakta, sonuç olarak inancından şüpheye düşmektedir.

"Lise eğitimini tamamlayan birey, ön yargı ve tutarsılılı konusunda bir yorum yapabilmelidir. Lise mezunu bireyler, olgu ile görüşü ayırt etme, temelsiz varsayımları saptama, ön yargı ve propagandayı fark etme, mantıklı çözümler üretme ve olası sonuçları tahmin etme gibi yetenekleri okul yıllarında kazanmış olmalıdırlar."6ı Bu açıdan, DKAB derslerinde, gençlerin karşılaştığı inanç, din, ahlâk ve günlük hayatla ilgili güncel sorular ya da problemlere çözüm getiren bir yaklaşım benimsenmelidir. ${ }^{62}$ Fakat ne yazık ki, bunun yapılabildiğini söylemek oldukça zordur. Dinî konularda karşılaştıkları problemleri çözme yeteneğini kazanamamış öğrenciler, menfî propaganda ve cereyanlardan kolaylıkla etkilenebilmektedirler.

Öğrenci dinî değerlere inanabilir veya inanmayabilir. İnanıp inanmama, onun hür seçiminin bir sonucu olacaktır. DKAB dersinin amacı, öğrencinin dinî olana tavır alışındaki bilinçliliği sağlamaktır. Din konusunda doğru ve geçerli davranışlar kazandırmaktır. Başka bir ifadeyle; yetişmekte olan nesle, din hakkında doğru bilgi vermek, onların toplumda yaygın olan zihniyetler üzerinde düşünerek bilinçlenmelerini sağlamaktır. ${ }^{63}$

Mesela; öğrencinin dinî inançlarını sarsabilecek kitaplarda ileri sürülen iddialardan biri, Hz. Peygamber'in Kur'ân ayetlerini Tevrat ve İncil'den kopye ettiği şeklindedir. Tevrat ve İncil, Kur'ân'dan önce nazil olduğu için, bu iddia, ögrencinin kafasında şüpheler doğurabilecek niteliktedir. Çünkü ögrenci, tarihi sadece kronolojik olarak bilmektedir. ${ }^{64} \mathrm{Bu}$ tür iddiaların gündeme getirilmesinin en önemli nedenlerinden birisi; bizlerin, tarihi, fikirlerle hadiselerin irtibatı açısından değil de, sadece kronolojik olarak bilmemiz ve gençlerimize böyle öğretmemizdir. Yani genel olarak eğitim, özel olarak da din eğitimi anlayışımızdaki boşluktur.

61 Özden, Eğitimde Dönüşüm, s. 23.

${ }^{62}$ Yavuz, a.g.e., s. 213.

63 Tosun, a.g.e., s. 159.

os Öğrencinin kronolojik tarih bilgisine göre, Hz. Muhammed'in risaletini tebliğinden önce Tevrat ve İncil insanların elinde bulunmaktadır. Olayları, eş zamanlı ve art zamanlı değerlendiremediğinden dolayı öğrenciye, Hz. Muhammed'in Tevrat ve İncil'i okumuş olması ihtimali makul gelebilecektir. Öğrencinin bu iddiayı, tarihteki nedenscllik ilkesine göre tahlil edip, çürütememesi durumunda inancının sarsılma ihtimali bulunmaktadır. 
Hz. Peygamber'e ilk vahyin gelmesi olayı, sadece tarih ve yer şeklinde değil de, hadise yorumlanarak ve karşılaştırmalar yapılarak, yani nedensellik ilkesine uyularak verildiyse; öğrenci bu bilgilerden hareketle yeni sonuçlara da ulaşarak, bu problemi çözebilecektir. "Öğrenciye tarih bilgisini kazandırmanın hedeflendiği bu tür konularda, sebep fikri başa geçmeli, zaman fikrinin ona tâbi olduğu bilinmelidir. Öğretmen, ta başlangıca götüren nedensellik zincirini koparıp, kendiliğinden hükümler vermemeli; geçmişte yaşanan olayları, bugünün olayları gibi, âdeta bizim tarafımızdan tekrar yaşanıyorlarmış̧̧asına ele almalıdır. Böylece ders, hafıza yükü olmaktan çıkarak, öğrencinin düşünmesini sağlayıcı bir mahiyet kazanmış olacaktır." ${ }^{\prime \prime}$

Hz. Peygamber'in, kendi kendisini Peygamber ilan etmediğinin çeşitli delilleri vardır. Peygamberliğin delillendirilmesi yöntemi, bizzat Kur'ân tarafından $\mathrm{Hz}$. Peygamber'e öğretilmiştir. Hz. Muhammed'le onun peygamberliğini inkâr edenler arasında geçen bir konuşmayı Kur'ân ayetlerine taşıyan Allah, Peygamberine şöyle buyurmaktadır: "De ki: Allah dileseydi ben onu (vahyi) size okumazdım. Size de bildirmemiş olurdum. Daha önce yıllarca aranızda bulundum. Hiç düşünmüyor musunuz?"66 Görüldüğü gibi Allah, Peygamber'inden sadece Peygamberliğini ilan etmekle yetinmemesini, mantıklı bir delillendirme yöntemi ile doğru söylediğini isbatlamasını istemektedir.

Pek çok Peygamber ile kavmi arasında geçen diyalogta da nübüvvetin delillendirilmesi yöntemine başvurulmuştur. Mesela Kur'ân'da anlatılan, $\mathrm{Hz}$. Nuh ile kavmi arasında geçen diyalog bunun bir örneğidir. Hz. Nuh'tan, kavmine Rabb'inden bir "delil" üzere olduğunu söylemesi istenmektedir ${ }^{67}$ $\mathrm{Hz}$. Nuh'un, yaptığı tebliğ görevi karşılığında bir ücret istememiş olması da, Kur'ân tarafından bir delil olarak ifade edilmektedir. ${ }^{68}$ Ayetlerde kullanılan delillerin öncülleri, kabulü zorunlu olan şeylerden seçilmiştir. ${ }^{69}$

Müslüman bilim adamları, Kur'ân'daki Peygamberliğin delillendirilmesi yönteminden yola çıkarak, bu konuda fikir üretmişlerdir. Hatta İslâm Felsefesi ve Kelam bilimlerinde "isbat-1 nübüvvet", "isbat-1 vacib"le birlikte önemli konulardan birisi hâline gelmiştir. ${ }^{70}$

\footnotetext{
is Top̧̧u, Türkiye'nin Maarif Davast, s. 124.

to Yunus, 10/16.

${ }^{67}$ Hud, $11 / 28$.

${ }^{68}$ Hud, 11/29.

*4 Muhammed Çelik, Kur'an'ın Ikna Hususiyeti, İzmir, 1996, Çağlayan Y., 267.

7 Mesela; İbn-i Sina, isbat-ı nübüvvet konusunda fikir üreten filozoflardan birisidir. O, "erRisale fi Isbat' in-Nübüvve" adlı eserinde, insan toplulukları içcrisinde onları yönlendiren üstün niteliklere sahip bir Peygamber'in niçin bulunması gerektiğini açıklamaktadır. Bkz. İbn-i Sina, "er-Risale fi İsbat'in-Nübüvve", Resayil fi'l-Hikmeti ve't-Tabiat, Kahire, 1989, Dar'ül-Arab Y., ss. 120-132., s. 123; İslâm Düşüncesi'nde nübüvvetin isbatı konusunda geniş bilgi için bkz. Salih Sabri Yavuz, Islâm Düşüncesinde Nübüvvet, İstanbul, İnsan Y., s. 168-175. Vahyi; Tanrı'dan dışarıya bir
} 
Peygamberlik müessesesinin, insanlık için gerekli olduğu ile ilgili delillerin nasıl üretildiğini ve onların mantığını kavrayan öğrenci, kendisi de yeni deliller üretebilecektir. Böylece, Hz. Muhammed'in Peygamberliğine olan inancı güçlenecektir.

Hz. Muhammed'in Peygamberliği konusu bu şekilde işlendiğinde, öğrencide şu davranışlar geliştirilmiş olacaktır:

1. Öğrenci, bu öğretim süreci sayesinde, olaylardan faydalanarak genellemeler yapma hususunda deneyim kazanacaktır. Bu deneyim, daha sonraki yaşantısında benzer durumlarla karşılaştı̆̆ında genelleme yaparak, bir sonuca ulaşma hususunda ona yardım edecektir. Bir öğretim sürecinde öğrencinin, içinde yaşadığı zaman diliminde karşılaştığı veya karşılaşacağı, zihninde şüphe ve tereddüt uyandiracak soru ve fikirlere cevaplar vermek (cevap vermeyi öğretmek) önemli değildir. Sorular ve fikirler zamanla değişecektir. Bütün soru ve fikirleri cevaplarıyla birlikte öğrenciye öğretim süresi boyunca öğretmek mümkün değildir. Önemli olan öğrenciye olayları eş ve art zamanlı düşünebilmeyi, bilinenlerle bilinmeyenler, alışılmışla beklenmedik arasında diyalektik bir münasebet kurarak genelleme yapmayı ve bir sonuca gitmeyi öğretmektir.

2. Herhangi bir konuda mantığa uygun düşünmeyi öğrenecektir. Mantı̆̆a uygun düşünebilme, sadece Din Kültürü ve Ahlâk Bilgisi dersinde değil, diğer derslerde de gerekli olan bir kabiliyettir.

3. Subjektif düşünce ve olaylar arasındaki farkı ayırt edebilecektir. İnsan, hayatı boyunca çok çeşitli düşünce ve fikirlerle karşılaşabilmektedir. Subjektif düşünce ile olay ve gerçekler arasını ayırt etmeyi öğrenen öğrenci, kazandığı bu bilinç sayesinde, karşılaştı̆̆ı her fikir ve görüşün etkisinde kalmayacak, doğru ve yanlışı kolaylikla belirleyebilecektir.

4. Öğrencinin mutlaka kendi geliştirdiği bazı fikir ve görüşleri vardır. Fakat, onları nasıl düzenleyeceğini bilememektedir. Yukarıda izah edilen bir öğretim süreci sonunda öğrenci, fikirlerini mantığa uygun bir yolda düzenleyebilecektir.

5. Bu tarzdaki bir öğretim süreci sonunda ögrenci, karşılaştı̆̆ı dinî içerikli bir problemin nasıl çözüleceğini öğrenmiş olacaktır.

6. Başkaları ile olan münasebetlerinde rasyonel bir şekilde düşünebilecektir. Bu durum, onun insanlarla olan ilişkilerine de olumlu bir şekilde yansıyacaktır. Sahip olduğu bir fikri, karşısındaki bir insana açıklarnayı, onu ikna etmeyi öğrenecektir.

taşma olarak nitelendiren İbn-i Sina, Peygamberi; bu taşmayı kabul edip insanlara iletebilecek üstün vasıflı bir insan olarak tarif etmektedir. Ona göre, vahyin Tanrı'dan dışarıya taşması ne kadar ıabii ise, onu alıp insanlara ulaştıracak bir kişinin bulunması da o kadar tabiidir. Bkz. İbn-i Sina, a.g.e., s. 124. 
7. Eğitimin ve din eğitiminin amaçlan açısından en önemlisi ise; fikir ve inançlarını mantıkî bir yolla savunabilecektir.

\section{Sonuç}

Din Kültürü ve Ahlâk Bilgisi dersinin genel amacı olan inançlı, bilgili ve iyi ahlâkh insan yetiştirme hedefi, dün olduğu gibi bugün de gözetilmektedir. Fakat, aynı olmayan bir şey vardır ki o da, bu niteliklere sahip insanın nasıl yetiştirileceğidir. Çok eskiden kalma öğretim yöntem ve teknikleriyle (ezbere dayalı), günümüzün değişen ve gelişen şartlarında yetişmiş, okuyan, düşünen ve sorgulayan gençlere her istediğimiz bilgiyi kolaylıkla öğretmek, en önemlisi ise benimsetmek mümkün gözükmemektedir. Artık gençler, araştırıp, sorguladıktan sonra, doğruluğuna karar verdikleri bilgileri öğrenmek istemektedirler. Hele hele ögrenmek zorunda bırakıldıkları bilgileri, özgürlüklerinin kısıtlandığı gerekçesiyle, gizli veya açık, çoğu zaman reddetmektedirler.

Bu nedenlerden dolayı, günümüz eğitim anlayışında, zihinsel öğretim süreçleri önem kazanmıştır. Öğrencinin zeka, düşünme, karşılaş̧ırma ve genelleme yapma, problem çözme gibi yeteneklerini geliştirerek, bilgileri bu yetenekler vasıtasıyle öğretmek, eğitimin genel amaçları arasında yerini almıştır. Aynı amaçlar, Din Kültürü ve Ahlâk Bilgisi dersi için de geçerlidir. Din Kültürü ve Ahlâk Bilgisi dersinde de, öğretim konusu yapılan bilgiler, öğrencilere zihinsel bir süreç yaşatılarak öğretilmeye çalışılmalıdır. Bu yapıldığı takdirde, dersin genel amaçlarına ulaşmak daha da kolaylaşacak, öğrenciler, bilinçli bir inanca sahip olacaklardır. Bilmedikleri dinî konuları, nasıl öğreneceklerini öğrenen öğrenciler, günlük hayatlarında karşılaştıkları dinî içerikli problemleri, daha kolay çözebileceklerdir. 